\title{
OPTIMAL PLANTING DENSITY FOR ACHIEVEING HIGHER YIELD AND FIBER QUALITY OF TWO TYPES OF COTTON (GOSSYPIUM HIRSUTUM L.)
}

\author{
YE, S. ${ }^{1}-$ JIANG, C. ${ }^{2}-$ LIU, F. ${ }^{1}-$ TIAN, C. ${ }^{1}-$ LI, C. ${ }^{1}-$ HAN, W. ${ }^{1}-$ WU, D. ${ }^{3 *}$ \\ ${ }^{I}$ Cotton Research Institute, Anhui Academy of Agricultural Sciences, Hefei 230001, China \\ ${ }^{2}$ Tobacco Research Institute, Anhui Academy of Agricultural Sciences, Hefei 230001, China \\ ${ }^{3}$ College of Agronomy, Anhui Agriculture University, Hefei 230036, China \\ *Corresponding author \\ e-mail: deixiangwu198@163.com; phone/fax: +86-551-6282-7187
}

(Received $1^{\text {st }}$ Feb 2021; accepted $16^{\text {th }}$ Apr 2021)

\begin{abstract}
Planting density is important for a high yield and quality of cotton, but still little is known about its effects on seed yield and fiber quality in Anhui province, China. A field experiment was carried out with two varieties (Wankemian-1 and Wanmian-191), and five planting densities (D1, D2, D3, D4, D5). Results showed that the boll number per plant and boll weight decreased significantly with increasing planting density. The highest yields of Wanmian-191 and Wankemian-1 were 3591.0 and $3504.5 \mathrm{~kg} \mathrm{ha}^{-1}$ in D2 and D4, respectively. It was estimated that the planting densities in Wanmian-191 and Wankemian-1 for the maximum seed yield were 79000 and 115000 plants $\mathrm{ha}^{-1}$, and the corresponding yields were 3610.3 and $3513.2 \mathrm{~kg} \mathrm{ha}^{-1}$, respectively. Suitable planting density increased the seed yield mainly by regulating the boll number per unit area and boll weight. Although the fiber quality was better for Wanmian-191 and Wankemian-1 under the planting density of 90000 and 79000 plants $\mathrm{ha}^{-1}$, in order to obtain high seed yield, quality and economic benefits, the optimal planting densities are 79000 and 115000 plants ha ${ }^{-1}$, respectively. There results will provide guideline for planting density to maximize yield and quality of cotton production in Anhui, China.
\end{abstract}

Keywords: cotton variety, fruit branch, fiber quality, lint yield, micronaire value

\section{Introduction}

Cotton (Gossypium hirsutum L.) is an important cash crop all over the world (Constable and Bange, 2015). Planting density is an important controllable factor in cotton production and has been paid more attention recently (Li et al., 2015; Zhi et al., 2015, 2016; Khan et al., 2017). There were many studies on the effect of density on cotton yield. Within a certain density range, plant height of cotton was increased with the increase of density (Dai et al., 2014). However, under a high density, the number of fruit branches, boll quality and lint percentage per plant were decreased, and the number of buds and bolls per plant were also decreased, and thus caused a decrease in the economic yield of cotton (Lou et al., 2010; Wang et al., 2012; Li et al., 2015). An appropriate planting density can offer a better ecological environment for the plant growth and development of cotton (Yang et al., 2014), to coordinate the contradiction between crop groups and individuals, and also to guarantee a certain number of groups. Therefore, the total number of the cotton plant, the boll number per plant, boll quality can be coordinated to produce higher seed cotton yield (Dong et al., 2012; Li et al., 2015). However, the suitable planting density was always different for different cotton varieties under different ecological conditions, so the optimum planting density must be determined by field experiments for each variety. 
The suitable planting density of cotton is mainly determined by the planting area, variety, pruning mode and soil fertility level (Chen et al., 2014; Li et al., 2015; Qi et al., 2020). The fruit branch types of cotton are mainly divided into finite fruit branch (compact) and infinite fruit branch (loose), and the degree of compact or loose of the plant has a decisive effect on the suitable planting density (Chen et al., 2014; Qi et al., 2020). Cotton varieties with limited fruit branches have reasonable plant type, good ventilation and light transmittance in the field, which can make full use of light energy, and are suitable for planting with high fertilizer and high density, which is conducive to improving the seed cotton yield (Chen et al., 2014). Generally, different planting areas also have large differences in planting densities, due to the large differences in cultivation techniques and soil fertility. For example, a high planting density was suitable for achieving a high yield in Xinjiang cotton region (Zhao et al., 2003; Zhu et al., 2020), and a reasonable dense planting was beneficial to increase yield in the Yellow River Basin (Zhou et al., 2018), however, a proper sparse planting was always used for obtaining higher weed cotton yield in the Yangtze River Basin in China (Wang et al., 2006).

Anhui is one of the major cotton planting provinces in China, with an annual cotton planting area of $350000 \mathrm{hm}^{2}$ (Zang et al., 2019). It is great important to study the optimal planting density of two cotton plant types (finite and infinite fruit branches) to increase the seed cotton yield and economic benefits in Anhui province. Therefore, this study explored the role of planting density on the plant growth characteristics, seed cotton yield and fiber quality of two cotton varieties (finite and infinite fruit branches), and achieved the suitable planting density for the two cotton varieties. There results will provide management guidelines to cotton growers for obtaining a high yield and economic benefits.

\section{Materials and methods}

\section{Experiment site and growth conditions}

The field experiment (Fig. 1) was conducted in 2016 on the experimental farm of the Cotton Research Institute, Anhui Academy of Agricultural Sciences, Anqing, Anhui, China $\left(30^{\circ} 31^{\prime} \mathrm{N}, 117^{\circ} 06^{\prime} \mathrm{E}\right)$. The field has a sandy loam soil with a $\mathrm{pH}$ of $8.0,11.9 \mathrm{~g}$ $\mathrm{kg}^{-1}$ organic matter, $57.5 \mathrm{mg} \mathrm{kg}$ alkaline nitrogen $(\mathrm{N}), 34.3 \mathrm{mg} \mathrm{kg}^{-1}$ available phosphorus $(\mathrm{P})$ and $102.4 \mathrm{mg} \mathrm{kg}^{-1}$ available potassium $(\mathrm{K})$. The average temperatures from May to October was $22.3^{\circ} \mathrm{C}$, and the total rainfall was $1896 \mathrm{~mm}$ in 2016 .

\section{Experimental design and management}

The experiment included two cotton varieties (Wankemian-1 and Wanmian-191, a finite and infinite fruit branch variety, respectively) (Fig. 2), and five planting densities [67500 (D1), 82500 (D2), 97500 (D3), 112500 (D4), 127500 (D5) plants ha ${ }^{-1}$ ]. According to the fruit branch characteristics and the field growth of the varieties, the infinite fruit branch variety has more branches and bigger plant types, therefore, its planting density was relatively low, while the planting density of finite fruit branch variety was relatively higher. Therefore, D1, D2, D3, D4 were used for Wanmian-191, and D2, D3, D4, D5 for Wankemian-1. Each plot was $20 \mathrm{~m}^{2}(3.6 \mathrm{~m} \times 5.6 \mathrm{~m})$ and contained 6 rows. The row spacing was $60 \mathrm{~cm}$ for each treatment. Plant spacing of D1, D2, D3, D4 and D5 was 25, 20, 17, 15 and $13 \mathrm{~cm}$, respectively. The experiment was carried out with a randomized complete block design with three replicates. Fertilizers, at 
the rate $\left(\mathrm{kg} \mathrm{ha}^{-1}\right)$ of $180 \mathrm{~N}, 90 \mathrm{P}_{2} \mathrm{O}_{5}$ and $180 \mathrm{~K}_{2} \mathrm{O}$ with urea $(46 \% \mathrm{~N})$, compound fertilizer $\left(17 \% \mathrm{~N}, 17 \% \mathrm{P}_{2} \mathrm{O}_{5}, 17 \% \mathrm{~K}_{2} \mathrm{O}\right)$ and potassium chloride $\left(60 \% \mathrm{~K}_{2} \mathrm{O}\right)$, were applied at early flowering (65 days after emergence). Other field managements were conducted according to local agronomic practices.

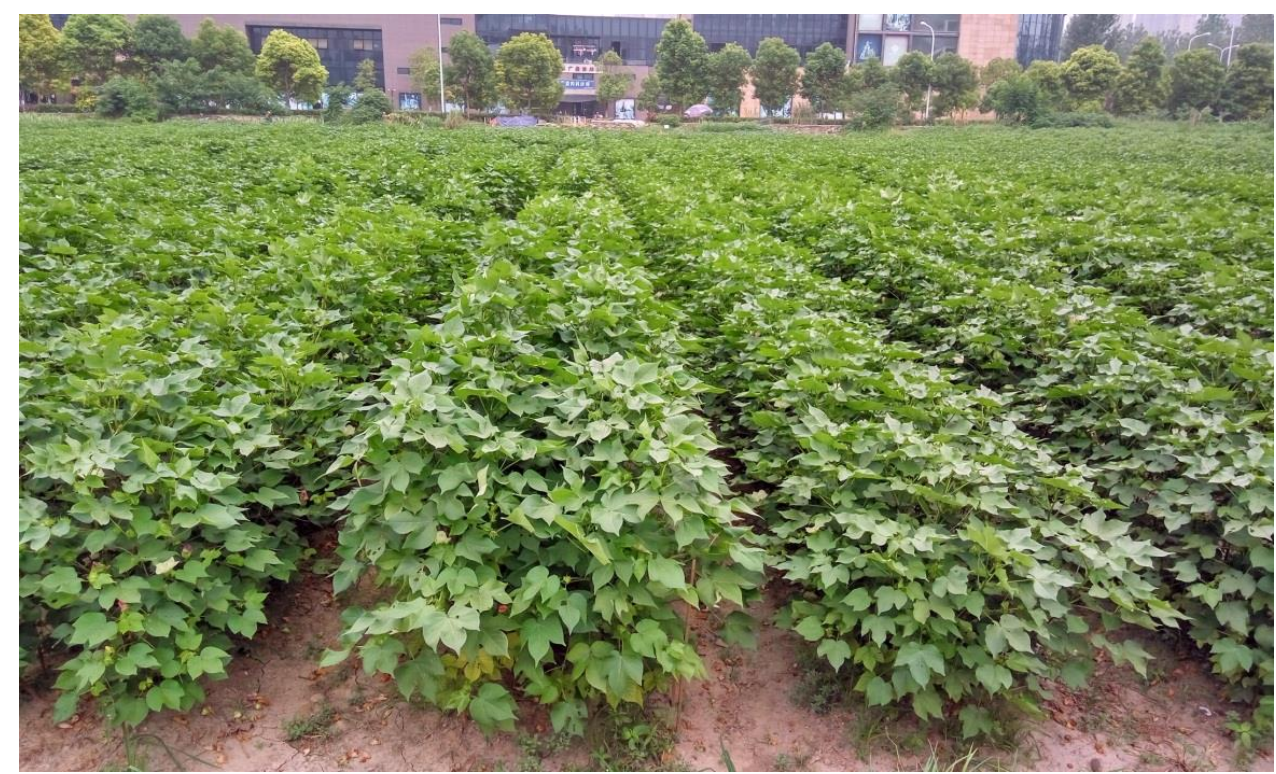

Figure 1. The field experiment
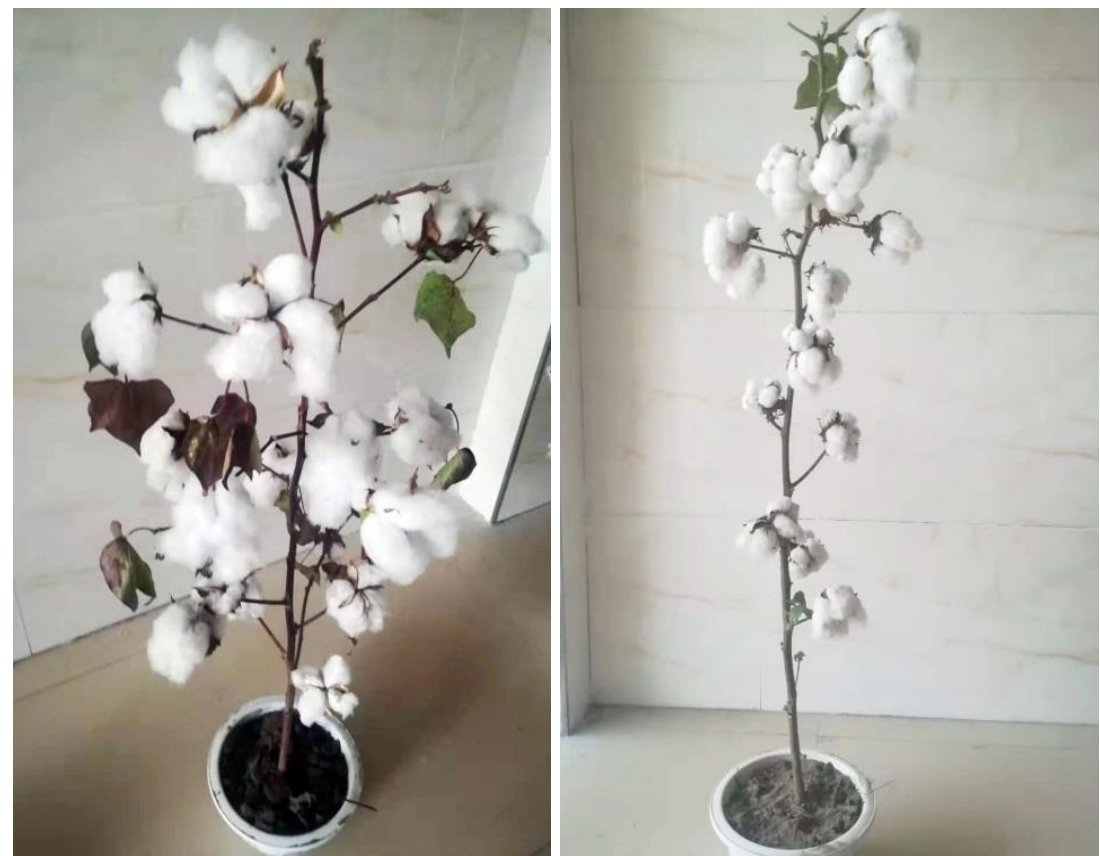

Figure 2. The two cotton varieties (left: Wanmian-191, right: Wankemian-1)

\section{Sample collection and determination}

Ten continue plants in the third row of each plot were selected to investigate the date of seedling emergence, squaring, first bloom and the opening (half of the plants were at 
first bloom) of the cotton plants. At peak boll stage (85 days after emergence), ten plants per plot were randomly selected to measure plant height, the first fruit node, and the number of fruit branch. Plants of each plot were manually harvested three times from September to October.

Seed cotton yield and lint yield were recorded three times from the manually harvested plants in each subplot. During each harvest, 50 bolls were randomly sampled per plot to determine boll weight and lint percentage. Number of bolls per plant and boll density were determined based on the three harvests (Zhi et al., 2016).

Fiber quality depends on fiber properties such as average fiber length, fiber strength, fiber uniformity, micronaire value (Bradow et al., 1997). Fiber quality parameters, namely upper half fiber length, fiber strength, fiber uniformity, fiber micronaire value and spinning consistence index, were analyzed according to the methods of Zhi et al. (2016) and Zhang et al. (2006).

\section{Statistical analysis}

Data were processed in Microsoft Excel 2013 and analyzed using SPSS 19.0 (SPSS Inc., Chicago, IL, USA). Means of the treatments were compared by the method of least significance difference at $P<0.05$.

\section{Results}

\section{Cotton plant growth stages and periods}

As shown in Table 1, the planting density did not significantly affect the emergence time of the cotton. However, both the squaring time and first bloom time of the cotton were increased with the increasing in plant density. The first bloom time was significant early in the low planting density (D1 and D2) than in the highest planting density (D4 and D5). However, the opening time was longer in D1 than other treatments for Wanmian-191, and longer in D2 than D5 for Wankemian-1. The growth period was decreased with the increasing in plant density.

Table 1. Effects of plant density on plant growth stages and periods of two cotton varieties

\begin{tabular}{c|c|c|c|c|c|c}
\hline \multirow{2}{*}{ Variety } & \multirow{2}{*}{ Density } & \multicolumn{4}{|c|}{ Growth stage (month-day) } & \multirow{2}{*}{ Growth period (d) } \\
\cline { 3 - 6 } & & Emergence & Squaring & First bloom & Opening & \\
\hline \multirow{3}{*}{ Wanmian-191 } & D1 & $05-28$ & $07-05$ & $08-01$ & $09-16$ & $111.7 \mathrm{a}$ \\
& D2 & $05-28$ & $07-06$ & $08-01$ & $09-14$ & $110.0 \mathrm{~b}$ \\
& D3 & $05-28$ & $07-07$ & $08-02$ & $09-14$ & $109.7 \mathrm{~b}$ \\
& D4 & $05-28$ & $07-08$ & $08-04$ & $09-14$ & $110.0 \mathrm{~b}$ \\
\hline \multirow{3}{*}{ Wankemian-1 } & D2 & $05-28$ & $07-03$ & $07-29$ & $09-14$ & $110.0 \mathrm{a}$ \\
& D3 & $05-28$ & $07-04$ & $07-30$ & $09-13$ & $109.0 \mathrm{ab}$ \\
& D4 & $05-28$ & $07-04$ & $08-01$ & $09-13$ & $109.3 \mathrm{a}$ \\
& D5 & $05-28$ & $07-05$ & $08-02$ & $09-12$ & $108.0 \mathrm{~b}$ \\
\hline Wanmian-191 & & & & & & $110.3 \mathrm{a}$ \\
\hline Wankemian-1 & & & & & $109.1 \mathrm{~b}$ \\
\hline
\end{tabular}

Means within a column of the same cotton variety that have different letters are significantly different from each other at $P<0.05$. The D1, D2, D3, D4 and D5 were respectively plant densities of 67500 , $82500,97500,112500,127500$ plants ha $^{-1}$ 


\section{Cotton plant growth characteristics}

As showed in Table 2, the first fruit node of the two cotton varieties decreased significantly with increasing plant density. Similarly, the number of fruit branch decreased significantly with increasing plant density in both Wanmian-191 and Wankemian-1. The plant height was highest at D3 of Wanmian-191, which was higher than that at the maximized density (D4). The plant height of Wankemian-1 decreased significantly with increasing plant density. The Wanmian-191 had higher first fruit node and plant height than the Wankemian-1, but lower number of fruit branch.

Table 2. Effects of plant density on plant growth characteristics of two cotton varieties

\begin{tabular}{c|c|c|c|c}
\hline Variety & Density & First fruit node & Number of fruit branch & Plant height (cm) \\
\hline \multirow{4}{*}{ Wanmian-191 } & D1 & $5.8 \mathrm{a}$ & $12.6 \mathrm{a}$ & $106.5 \mathrm{ab}$ \\
& $\mathrm{D} 2$ & $5.7 \mathrm{ab}$ & $12.1 \mathrm{a}$ & $110.0 \mathrm{ab}$ \\
& $\mathrm{D} 3$ & $5.7 \mathrm{ab}$ & $10.2 \mathrm{~b}$ & $112.2 \mathrm{a}$ \\
& $\mathrm{D} 4$ & $5.6 \mathrm{~b}$ & $9.5 \mathrm{~b}$ & $105.4 \mathrm{~b}$ \\
\hline \multirow{3}{*}{ Wankemian-1 } & $\mathrm{D} 2$ & $5.3 \mathrm{a}$ & $14.2 \mathrm{a}$ & $105.5 \mathrm{a}$ \\
& $\mathrm{D} 3$ & $5.2 \mathrm{ab}$ & $13.5 \mathrm{ab}$ & $102.2 \mathrm{ab}$ \\
& $\mathrm{D} 4$ & $5.1 \mathrm{bc}$ & $12.8 \mathrm{~b}$ & $100.3 \mathrm{ab}$ \\
& $\mathrm{D} 5$ & $5.0 \mathrm{c}$ & $10.2 \mathrm{c}$ & $95.2 \mathrm{~b}$ \\
\hline Wanmian-191 & & $5.7 \mathrm{a}$ & $11.1 \mathrm{~b}$ & $108.5 \mathrm{a}$ \\
\hline Wankemian-1 & & $5.2 \mathrm{~b}$ & $12.7 \mathrm{a}$ & $100.8 \mathrm{~b}$ \\
\hline
\end{tabular}

Means within a column of the same cotton variety that have different letters are significantly different from each other at $P<0.05$. The D1, D2, D3, D4 and D5 are respectively plant densities of 67500 , $82500,97500,112500,127500$ plants ha ${ }^{-1}$

\section{Yield and yield components}

The effect of plant density on yield and yield components of the two cotton varieties were showed in Table 3. The boll number of per plant decreased significantly with increasing plant density, and the boll number in D4 was decreased by $36 \%$ compared with D1 in Wanmian-191. Similarly, the boll weight decreased with increasing plant density, the boll weight was maximized at the lowest density for both the Wankemian-1 and Wanmian-191. However, there was no significant differences in boll weight between D1 and D2 for Wanmian-191, and was also no significant differences for Wankemian-1 in the density of D1, D2 and D3. Conversely, the lint percentage increased as plant density increased in both Wanmian-191 and Wankemian-1. The seed cotton yield and lint yield were increased with increasing plant density and then decreased when plant density was over certain level. The highest seed cotton yield and lint yield of Wanmian-191 and Wankemian-1 was found in the density of D2 and D4, respectively. And no significant differences in the highest seed cotton yield between two cultivars were observed. The Wanmian-191 had higher boll number, boll density and lint percentage than the Wankemian-1. However, no significant differences in the boll weight, seed cotton yield and lint yield between the two cultivars were observed.

According to the relationship between yield (y) and density ( $\mathrm{x}$ ), a quadratic regression equation $\left(y=a x^{3}+b x^{2}+c x+d\right)$ was established to describe the change of seed cotton yield with planting density (Fig. 3). As shown in Table 4, it was calculated that the planting density in Wanmian-191 and Wankemian-1 for the maximum seed 
cotton yield was 115000 and 79000 plants $\mathrm{ha}^{-1}$, and the corresponding seed cotton yields were 3610.3 and $3513.2 \mathrm{~kg} \mathrm{ha}^{-1}$, respectively.

Table 3. Effects of plant density on yield and yield components of two cotton varieties

\begin{tabular}{|c|c|c|c|c|c|c|c|}
\hline Variety & Density & $\begin{array}{l}\text { Boll number } \\
\left.\text { (boll plant }^{-1}\right)\end{array}$ & 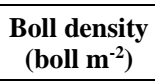 & $\begin{array}{c}\text { Boll weight } \\
\left(\mathrm{g} \text { boll }^{-1}\right)\end{array}$ & \begin{tabular}{|c|} 
Lint \\
percentage (\%) \\
\end{tabular} & \begin{tabular}{|c|}
$\begin{array}{c}\text { Seed cotton } \\
\text { yield }\left(\mathbf{k g} \cdot \mathrm{ha}^{-1}\right)\end{array}$ \\
\end{tabular} & $\begin{array}{c}\text { Lint yield } \\
\left(\mathrm{kg} \cdot \mathrm{ha}^{-1}\right)\end{array}$ \\
\hline \multirow{4}{*}{ Wanmian-191 } & D1 & $15.6 \mathrm{a}$ & $105.3 \mathrm{~b}$ & $5.2 \mathrm{a}$ & $40.1 \mathrm{c}$ & $3204.7 \mathrm{~b}$ & $1285.1 \mathrm{~b}$ \\
\hline & $\mathrm{D} 2$ & $14.2 \mathrm{~b}$ & $117.2 \mathrm{ab}$ & $5.0 \mathrm{a}$ & $40.5 \mathrm{bc}$ & $3591.0 \mathrm{a}$ & $1454.4 \mathrm{a}$ \\
\hline & D3 & $12.1 \mathrm{c}$ & $118.0 \mathrm{a}$ & $4.6 \mathrm{~b}$ & $40.8 \mathrm{ab}$ & $3170.2 \mathrm{~b}$ & $1293.4 \mathrm{~b}$ \\
\hline & D4 & $10.2 \mathrm{~d}$ & $114.8 \mathrm{ab}$ & $4.4 \mathrm{~b}$ & $41.0 \mathrm{a}$ & $3009.8 \mathrm{~b}$ & $1234.0 \mathrm{~b}$ \\
\hline \multirow{4}{*}{ Wankemian-1 } & D2 & $11.2 \mathrm{a}$ & $92.4 \mathrm{~b}$ & $5.2 \mathrm{a}$ & $38.9 \mathrm{c}$ & $2889.1 \mathrm{c}$ & $1123.9 \mathrm{c}$ \\
\hline & D3 & $10.1 \mathrm{~b}$ & $98.5 \mathrm{ab}$ & $5.1 \mathrm{a}$ & $39.2 \mathrm{bc}$ & $3178.8 \mathrm{~b}$ & $1246.1 \mathrm{~b}$ \\
\hline & D4 & $9.6 \mathrm{~b}$ & $108.0 \mathrm{a}$ & $5.0 \mathrm{ab}$ & $39.8 \mathrm{ab}$ & $3504.5 \mathrm{a}$ & $1394.8 \mathrm{a}$ \\
\hline & D5 & $8.5 \mathrm{c}$ & $108.4 \mathrm{a}$ & $4.6 \mathrm{~b}$ & $40.2 \mathrm{a}$ & $3146.7 \mathrm{~b}$ & $1265.0 \mathrm{~b}$ \\
\hline Wanmian-191 & & $13.0 \mathrm{a}$ & $113.8 \mathrm{a}$ & $4.8 \mathrm{a}$ & $40.6 \mathrm{a}$ & $3243.8 \mathrm{a}$ & $1316.7 \mathrm{a}$ \\
\hline Wankemian-1 & & $9.9 \mathrm{~b}$ & $101.8 \mathrm{~b}$ & $5.0 \mathrm{a}$ & $39.5 \mathrm{~b}$ & $3179.6 \mathrm{a}$ & $1257.3 \mathrm{a}$ \\
\hline
\end{tabular}

Means within a column of the same cotton variety that have different letters are significantly different from each other at $P<0.05$. The D1, D2, D3, D4 and D5 were respectively plant densities of 67500, 82500, 97500, 112500, 127500 plants ha $^{-1}$
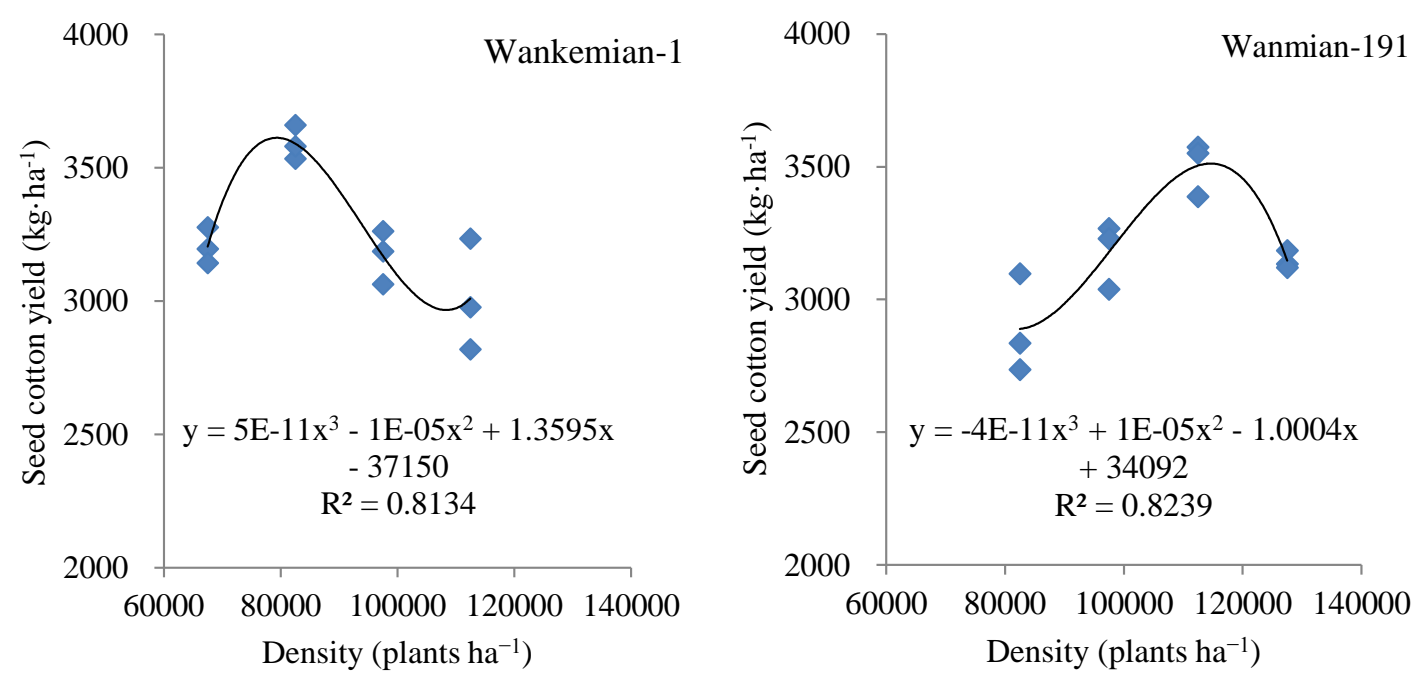

Figure 3. Effect of planting density on seed cotton yield of two cotton varieties. Data were the means of twelve replicates

Table 4. Planting density for maximum seed cotton yield of two cotton varieties

\begin{tabular}{|c|c|c|}
\hline Variety & $\begin{array}{l}\text { Plant density of maximum yield } \\
\left(\text { plants ha }{ }^{-1}\right)\end{array}$ & $\begin{array}{c}\text { Maximum seed cotton yield } \\
\left(\mathrm{kg} \cdot \mathrm{ha}^{-1}\right)\end{array}$ \\
\hline Wanmian-191 & 79000 & 3610.3 \\
\hline Wankemian-1 & 115000 & 3513.2 \\
\hline
\end{tabular}

\section{Fiber quality parameters}

The effects of plant density on fiber quality parameters of two cotton varieties were showed in Table 5. The upper half fiber length of the Wankemian-1 and Wanmian-191 under different densities was between 29.6 and $31.7 \mathrm{~mm}$, and no significant differences 
in the upper half fiber length were observed in Wankemian-1 under different planting densities. The fiber strength of the Wankemian-1 and Wanmian-191 was between 29.2 and $32.9 \mathrm{cN} \cdot$ tex $^{-1}$, and the fiber strength was the highest in D2 for Wankemian-1, and in D3 for Wanmian-191. The micronaire value and uniformity index increased with increasing density in Wanmian-191, while the micronaire value was decreased with increasing density in Wankemian-1. The upper half fiber length, fiber strength and spinning consistence index were higher in Wankemian-1 than that in Wanmian-191. No significant differences in the micronaire value and uniformity index between the two cultivars were found. In all, most of the fiber quality parameters were higher in D3 and D1 for Wanmian-191 and Wankemian-1, respectively.

Table 5. Effects of plant density on fiber quality parameters of two cotton varieties

\begin{tabular}{c|c|c|c|c|c|c}
\hline Variety & Density & $\begin{array}{c}\text { Upper half } \\
\text { fiber length } \\
(\mathbf{m m})\end{array}$ & $\begin{array}{c}\text { Fiber strength } \\
\left(\mathbf{c N} \cdot \mathbf{t e x}^{-1}\right)\end{array}$ & $\begin{array}{c}\text { Micronaire } \\
\text { value }\end{array}$ & $\begin{array}{c}\text { Uniformity } \\
\text { index (\%) }\end{array}$ & $\begin{array}{c}\text { Spinning } \\
\text { consistence } \\
\text { index (SCI) }\end{array}$ \\
\hline \multirow{2}{*}{ Wanmian-191 } & D1 & $30.5 \mathrm{a}$ & $30.8 \mathrm{a}$ & $5.05 \mathrm{ab}$ & $84.9 \mathrm{c}$ & $135.0 \mathrm{~b}$ \\
& $\mathrm{D} 2$ & $29.6 \mathrm{~b}$ & $29.5 \mathrm{~b}$ & $4.83 \mathrm{~b}$ & $85.8 \mathrm{~b}$ & $136.0 \mathrm{~b}$ \\
& D3 & $30.7 \mathrm{a}$ & $30.9 \mathrm{a}$ & $5.20 \mathrm{ab}$ & $86.7 \mathrm{a}$ & $141.0 \mathrm{a}$ \\
& $\mathrm{D} 4$ & $30.7 \mathrm{a}$ & $29.2 \mathrm{~b}$ & $5.38 \mathrm{a}$ & $86.7 \mathrm{a}$ & $136.0 \mathrm{~b}$ \\
\hline \multirow{3}{*}{ Wankemian-1 } & $\mathrm{D} 2$ & $31.5 \mathrm{a}$ & $32.9 \mathrm{a}$ & $5.30 \mathrm{a}$ & $86.4 \mathrm{ab}$ & $147.0 \mathrm{a}$ \\
& $\mathrm{D} 3$ & $31.5 \mathrm{a}$ & $30.9 \mathrm{~b}$ & $4.90 \mathrm{~b}$ & $86.6 \mathrm{ab}$ & $147.0 \mathrm{a}$ \\
& $\mathrm{D} 4$ & $31.7 \mathrm{a}$ & $29.9 \mathrm{~b}$ & $4.82 \mathrm{~b}$ & $86.2 \mathrm{~b}$ & $145.0 \mathrm{a}$ \\
\hline Wanmian-191 & $\mathrm{D} 5$ & $30.9 \mathrm{a}$ & $30.8 \mathrm{~b}$ & $4.86 \mathrm{~b}$ & $87.0 \mathrm{a}$ & $148.0 \mathrm{a}$ \\
\hline Wankemian-1 & & $30.4 \mathrm{~b}$ & $30.1 \mathrm{~b}$ & $5.12 \mathrm{a}$ & $86.0 \mathrm{a}$ & $137.0 \mathrm{~b}$ \\
\hline
\end{tabular}

Means within a column of the same cotton variety that have different letters are significantly different from each other at $P<0.05$. The D1, D2, D3, D4 and D5 were plant densities of 67500, 82500, 97500, 112500,127500 plants ha ${ }^{-1}$, respectively

\section{Discussion}

\section{Effects of plant density on the growth and yield of cotton}

Planting density is one of the major control measures of cotton production, it can regulate the growth and development of cotton leaves and agronomic traits (Wang et al., 2020). Plant height, number of branches and stem diameter are important agronomic traits in cotton cultivation. Previous studies have shown that plant height increased with the increase of density (Li et al., 2011; Khan et al., 2017). However, Zhou et al. (2019) found that planting density had little influence on plant height. In this study, the plant height of the Wankemian-1 tended to decrease with the increase of the planting density, and the plant heigh of the Wanmian-191 also was lower in D4 than that in D3 (Table 2). This result is consistent with the research of Khan et al. (2017) who suggested that planting density has a certain influence on plant height, and plant height tended to decrease with the increase of density. The main reason for the difference of plant height between the two cotton varieties affected by planting density in this study may be due to that the Wankemian-1 is an infinite fruit branch with a large area per plant, so the increase of density significantly affects the plant growth, and the plant height decreases with the increase of density, while the Wanmian-191 belongs to a finite fruit branch, 
which each plant occupies a small area, so the plant growth was not significantly affected by the density. With the increase of planting density, the number of fruit branch of the two cotton varieties showed a decreasing trend, which was similar to the results of previous studies (Li et al., 2011). In general, due to plant type difference, the number of fruit branch of Wankemian-1 decreased more sharply with the increase of density, suggesting that Wankemian- 1 is more suitable for low-density planting.

Planting density is the main means to regulate crop growth and dry matter accumulation, and has great regulatory effect on the growth and development, and the yield of cotton (Wang et al., 2020). Suitable density can coordinate the relationship between the population and the individual, make the individual grow robust without premature senescence, and ensure a suitable number of plant groups, the boll number and boll weight of cotton (Wang et al., 2020). Studies have shown that both the lint yield and seed cotton yield are not the highest under the high density or low density planting modes, however, a reasonable planting density is the main factor to obtain a high yield of cotton (Zhang et al., 2004). Therefore, suitable planting density has become the main way to increase cotton yield. In this study, it was found that the cotton yield increased first and then decreased with the increase of planting density. When the planting density was too high, the cotton yield decreased (Table 3). The optimal planting density was different in different cotton planting areas in China. It was reported that the suitable density of insectresistant hybrid cotton was 30000 plants ha ${ }^{-1}$ in the lower reaches of the Yangtze River Basin (Liu et al., 2010). The suitable planting density of cotton was between 51000 to 87000 plants ha ${ }^{-1}$ in the North Plain of China (Zhang et al., 2016). And the density of high lint yield for cotton was about 180000 plants ha ${ }^{-1}$ in Xinjiang (Zhang et al., 2004). However, the most common plant density recommendation to optimize yield for cotton is about 81000 plants ha ${ }^{-1}$ in the United States (Adams et al., 2019). In this study, it was concluded that planting density of 82500 plants ha $^{-1}$ (D2) for Wanmian-191 and 112500 plants ha ${ }^{-1}$ (D4) Wankemian-1 in Anhui cotton region produced the highest yields. The Wankemian-1 belongs to finite fruit branch, and its suitable cultivation density is larger than Wanmian-191, because the cotton variety of infinite fruit branch has reasonable plant type, good ventilation and light in the field, which can make full use of light energy, and is suitable for cultivation with high fertilizer and high density for increasing the yield per unit area of cotton (Chen et al., 2014). Some studies suggested that the planting density of cotton varieties with finite fruit branch was 75000-120000 plants ha ${ }^{-1}$, which can effectively solve the contradiction between the individual and the population to achieve a high yield (Chen et al., 2014).

In this study, among the yield components, boll number per plant and boll weight decreased with the increase of planting density, which was consistent with the study of Zhi et al. (2016). This study revealed that the increase of cotton yield was mainly due to the increase of boll number per unit area. Previous study also showed that the total boll number per unit area increased with the increase of planting density (Zhou et al., 2019; Zhi et al., 2016). However, when the planting density is too high, the total boll number per unit area will not increase and boll weight will significantly decrease, which is consistent with the results of previous studies (Khan et al., 2017). Therefore, the yield will significantly decrease if the density is too high. In order to achieve the maximum yield, an appropriate planting density must be selected to obtain a higher boll weight per unit area and boll number per unit area. In this study, in order to obtain the highest yield, the planting densities of Wanmian-191 and Wankemian-1 should be selected as 79000 and 115000 plants ha ${ }^{-1}$, respectively, according to a regression equation (Fig. 3; Table 4). 


\section{Effects of plant density on the fiber quality of cotton}

Fiber quality of cotton depends on fiber properties including average fiber length, fiber strength, fiber uniformity, micronaire value (Bradow et al., 1997). The quality of cotton fiber is mainly determined by genotype, and also influenced by the climatic and cultivation condition. Previous researches showed that planting density had no significant effect on fiber quality of the variety ' $\mathrm{Ji}$ 863', but had a significant influence on the fiber quality of 'Shikang126' except the upper half fiber length (Zhou et al., 2019). The different effects of planting density on fiber quality between the 'Ji 863' and 'Shikang126' may be due to the stability of the variety. In this study, the upper half fiber length, fiber strength and spinning consistence index were not significant affected by planting densities, while they were significant different between the two cotton varieties (Table 5). Therefore, our study suggested that the quality of fiber were affected by the variety rather than by the planting density. Zhang et al. (2019) also found that planting density had no significant effect on cotton fiber quality. Similar results were also obtained by Bridge et al. (1973), who found that fiber quality was not closely related to planting density. However, the results of Zhou et al. (2018) indicated that the micronaire value showed a trend of first decreasing and then increasing with the increase of planting density. Wang et al. (2010) also found that the increase of density slightly improved the fiber length and macronaire value. These results were evidenced in the present study of the infinite fruit branch variety (Wanmian-191), but not in the finite fruit branch variety (Wankemian-1). These results indicated that the appropriate planting density is an important way to optimize cotton population and improve fiber quality for the infinite fruit branch variety (Zhi et al., 2015, 2016; Zhang et al., 2019; Zhou et al., 2019). In general, cotton fiber quality was affected by the interaction between genotype and environment. Cultivation condition and environment have influence on the formation of cotton fiber quality in some varieties (Darawsheh et al., 2009), but not in other varieties. Bednarz et al. (2006) pointed out that reducing density can increase the souring-pool ratio at the filling stage of inner fruiting node and thus improve fiber quality, which was the same for the finite fruit branch variety Wankemian-1 in this study. The fiber quality was highest under planting density of 90000 plants ha ${ }^{-1}$, which the yield was highest under density of 79000 plants $^{-1} a^{-1}$ for Wanmian-191. The high quality of fiber for Wankemian-1 was 82500 plants ha ${ }^{-1}$, but was lower than the highest yield density (115000 plants ha-1 ${ }^{-1}$.

\section{Conclusion}

This study explored the effect of planting density on the plant growth characteristics, seed cotton yield and fiber quality of two cotton varieties (finite fruit branch Wankemian-1 and infinite Wanmian-191). The highest yields of Wanmian-191 and Wankemian-1 were 3591.0 and $3504.5 \mathrm{~kg} \mathrm{ha}^{-1}$ under the planting densities of 82500 and 112500 plants ha ${ }^{-1}$, respectively. Suitable planting density increased the seed cotton yield mainly by regulating the boll number per unit area and boll weight. In conclusion, in order to obtain high seed cotton yield, quality and economic benefits, the optimal planting densities for Wanmian-191 and Wankemian-1 would be 79000 and 115000 plants ha ${ }^{-1}$, respectively, in Anhui cotton region, China. Although the results of this study may need to be verified by further multiple-year experiments, the suitable planting density of the two varieties provided useful reference and guidance for the fellow researchers and cotton growers. 
Acknowledgements. This study was funded by National Transgenic New Species Breeding Major Project of China (2016ZX08005-001-009) and the Discipline Construction Project of Anhui Academy of Agricultural Sciences (2021 YL078).

\section{REFERENCES}

[1] Adams, C., Thapa, S., Kimura, E. (2019): Determination of a plant population density threshold for optimizing cotton lint yield: a synthesis. - Field Crops Research 230: 11-16.

[2] Bednarz, C. W., Nichols, R. L., Brown, S. M. (2006): Plant density modifies withincanopy cotton fiber quality. - Crop Science 46(2): 950-956.

[3] Bradow, J. M., Bauer, P. J., Hinojosa, O., Sassenrath-Cole, G. (1997): Quantitation of cotton fibre-quality variations arising from boll and plant growth environments. - Europe Journal Agronomy 6: 191-204.

[4] Bridge, P. R., Meredith, W. R., Chism, J. F. (1973): Influence of planting method and plant population on cotton (Gossypium hirsutum L.). - Agronomy Journal 65(1): 104109.

[5] Chen, Q., Han, X., Lan, J., Huang, Y., Fu, J., Zhang, Z. (2014): Development of upland cotton varieties of short fruiting branch and analysis of its application in Hubei province. - Cotton Sciences 36(6): 6-9.

[6] Constable, G. A., Bange, M. P. (2015): The yield potential of cotton (Gossypium hirsutum L.). - Field Crops Research 182: 98-106.

[7] Dai, M., Wu, Z., Liu, L., Ma, J. (2014): Influence of planting density on development, yield and quality of upland cotton. - Acta Agriculturae Boreali-Sinica 29(Supp.): 146154.

[8] Darawsheh, M. K., Chachalis, D., Khah, E. M. (2009): Cotton row spacing and plant density cropping systems II. Effects on seed cotton yield, boll components and lint quality. - Journal of Food, Agriculture \&Environment 7(3/4): 262-265.

[9] Dong, H. Z., Li, W. J., Eneji, A. E., Zhang, D. M. (2012): Nitrogen rate and plant density effects on yield and late-season leaf senescence of cotton raised on a saline field. - Field Crops Research 126(2): 137-144.

[10] Khan, A., Najeeb, U., Wang, L., Tan, D. K. Y., Yang, G., Munsif, F., Ali, S., Hafeez, A. (2017): Planting density and sowing date strongly influence growth and lint yield of cotton crops. - Field Crops Research. 209: 129-135.

[11] Li, P., Dong, H., Liu, A., Liu, J., Sun, M., Wang, G., Liu, S., Zhao, X., Li, Y. (2015): Effects of planting density and nitrogen fertilizer interaction on yield and nitrogen use efficiency of cotton. - Transactions of the Chinese Society of Agricultural Engineering (Transactions of the CSAE) 31(23): 122-130.

[12] Li, Y., Li, J., Yang, C., Guo, L. (2011): Effects of different planting densities on agronomic traits and yield components of hybrid cotton. - Hunan Agricultural Sciences 5: 38-40, 50.

[13] Liu, R. X., Shi, W., Xu, L. H., Yang, C. Q., Guo, W. Q., Zhang, P. T. (2010): Planting density of insect-resistant hybrid cotton in lower reaches of Yangtze River Valley. Cotton Sciences 22: 634-638.

[14] Lou, S., Zhao, Q., Gao, Y., Guo, R., Abuli, K., Zhang, J. (2010): The effect of different density to canopy-microclimate and quality of cotton. - Cotton Sciences 22(3): 260-266.

[15] Qi, H., Zhao, W., Shao, R., Zhang, D., Li, F., Dong, L., Yang, X., Shi, J. (2020): Effects of pruning on yield and fiber quality of different cotton varieties. - Cotton Sciences 42(1): 26-31.

[16] Wang, X., Bao, K., Song, L. (2006): Problems in sparse planting and cultivation of cotton and improvement measures. - Anhui Agricultural Science Bull 12(6): 100. 
[17] Wang, S., Liu, J., Sun, G., Xu, F., Lin, Y., Qi, H., Wang, Z., Li, Z. (2010): Study on screening the suitable planting density of cotton in central Hebei. - Journal of Hebei Agricultural Science 14(1): 6-7.

[18] Wang, Z., Wu, X., Zhang, G., Jin, L., Shan, Y., Wu, X., Zhou, Z. (2012): Effects of planting density on biomass and nitrogen accumulation in cotton, Northeast China. Cotton Science 24(1): 35-43.

[19] Wang, S., Yang, Z., Shi, J., Li, H., Song, X., Sun, X. (2020): Effects of increasing planting density and decreasing nitrogen rate on dry matter, nitrogen accumulation and distribution, and yield of cotton. - Acta Agronomica Sinica 46(3): 395-407.

[20] Yang, G. Z., Jiao, L. X., Chun, N. Y., Long, Z. X. (2014): Effects of plant density on yield and canopy micro environment in hybrid cotton. - Journal of Integrative Agriculture 13(10): 2154-2163.

[21] Zang, Y., Hang, W., Qi, M., Ye, S., Liu, F. (2019): The present situation of cotton industry in Anhui province and the reform measures of revitalizing cotton industry. Cotton Sciences 41(5): 3-7.

[22] Zhang, W. F., Wang, Z. L., Yu, S. L., Li, S. K., Fang, J., Tong, W. S. (2004): Effects of planting density on canopy photosynthesis, canopy structure and yield formation of highyield cotton in Xinjiang, China. - Acta Phytoecologica Sinica 28: 164-171.

[23] Zhang, L., Meng, Y., Xue, X., Chen, B., Xiong, Z., Zhou, Z. (2006): Establishing model of an integrated fiber-quality index. - Scientia Agricultura Sinica 39(6): 1130-1137.

[24] Zhang, D. M., Luo, Z., Liu, S. H., Li, W. J., Tang, W., Dong, H. Z. (2016): Effects of deficit irrigation and plant density on the growth, yield and fiber quality of irrigated cotton. - Field Crops Research 197: 1-9.

[25] Zhang, H., Yan, Z., Zhao, S., Huang, X., Dai, B., Li, W. (2019): Effects of different densities, nitrogen application rates and fertilizer patterns on yield and fiber quality of cotton variety Gang 86. - Hubei Agricultural Sciences 58(22): 46-48.

[26] Zhao, Z., Tian, C. Y., Ma, Y. J. (2003): Influence of close planting on the yield and quality of cotton. - Arid Zone Res. 20(4): 292-295.

[27] Zhi, X. Y., Mao, S. C., Han, Y. C., Li, Y. B., Du, W. L., Li, X. X., Wang, G. P., Fan, Z. Y., Yang, B. F., Feng, L. (2015): Effects of cultivars and planting density on yield components and seed characteristics on cotton. - Cotton Science 27: 216-222.

[28] Zhi, X., Han, Y., Li, Y., Wang, G., Du, W., Li, X., Mao, S., Feng, L. (2016): Effects of plant density on cotton yield components and quality. - Journal of Integrative Agriculture 15(7): 1469-1479.

[29] Zhou, Y. P., Du, H. Y., Tian, H. Y., Ge, C. H., Yan, J. Z., Sun, J., Shi, S. X. (2018): The influence of different planting densities on growth and yield of cotton. - Journal of Arid Land Resources and Environment 32(4): 95-99.

[30] Zhou, Y. P., Tian, H. Y., Cui, R. M. (2019): Planting densities: effects on growth, yield and quality of 3 cotton varieties. - Journal of Agriculture 9(12): 5-8.

[31] Zhu, X., Luo, P., Zhang, J., Xu, Y., Guan, L. (2020): Effects of different cotton varieties and density on yield in eastern Xinjiang. - Cotton Sciences 42(5): 40-44. 